\title{
مقدمة في دراسة اللفة العبريّة السامريّة
}

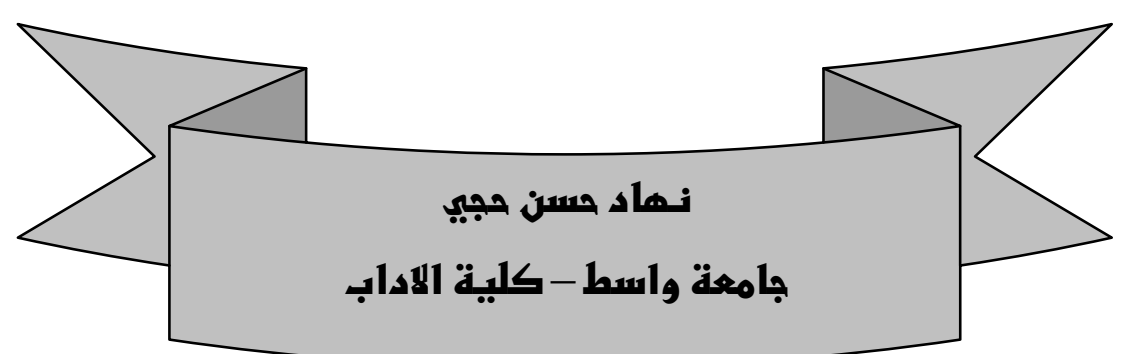

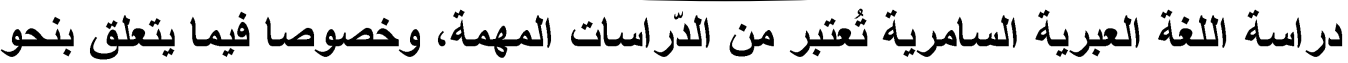

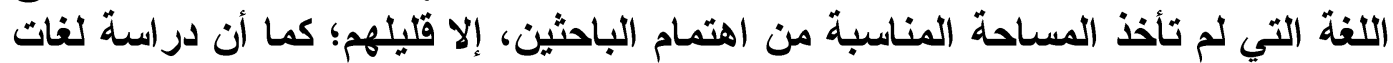

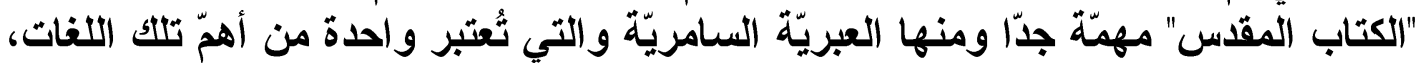

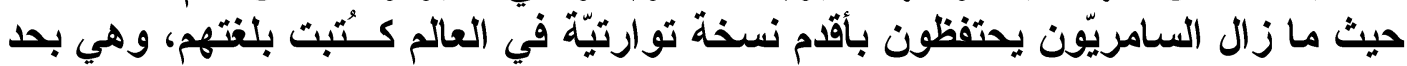

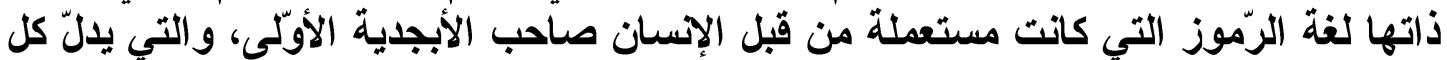

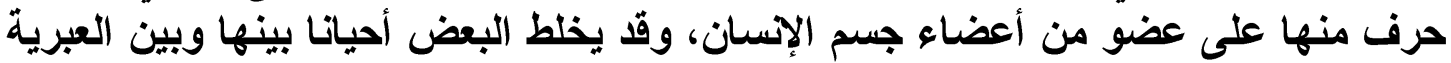

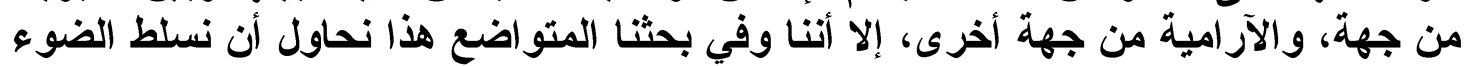

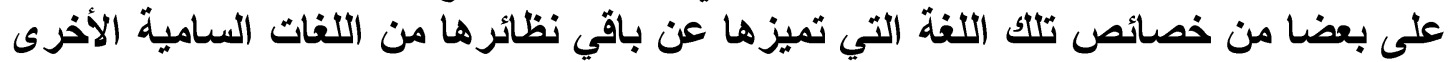

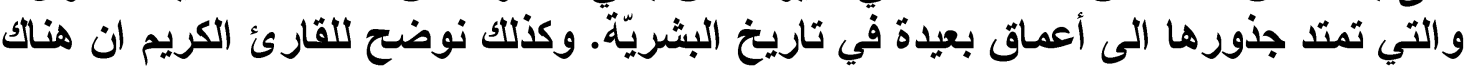

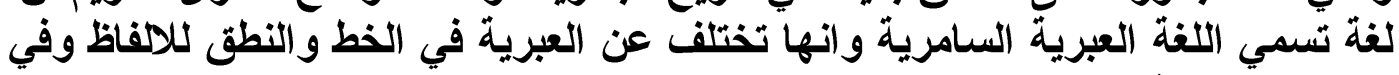
القو اعد النحوية.

\section{أصل السامريين:}

اختلفت الآراء حول هذا الموضوع 1، إذ يعتقد اليهود أنّ السامريّين ليسوا من بني

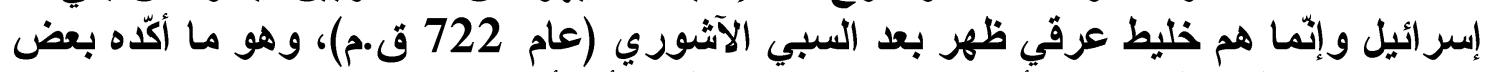

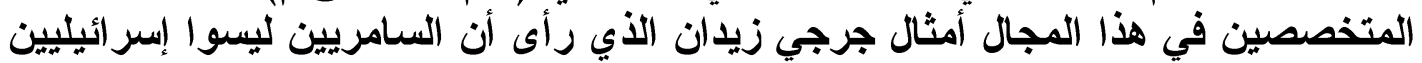

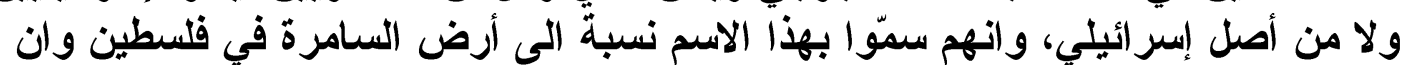

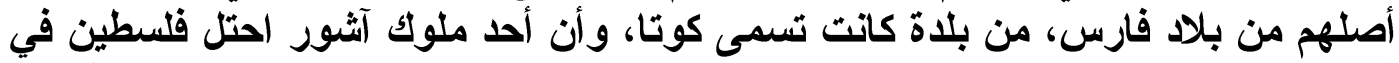

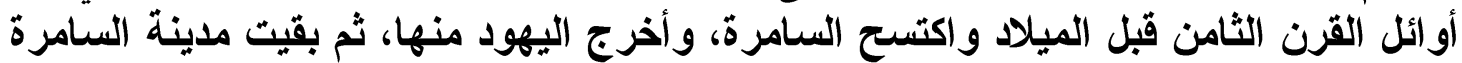

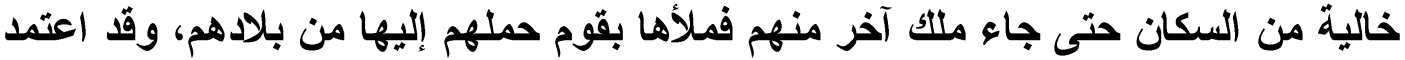

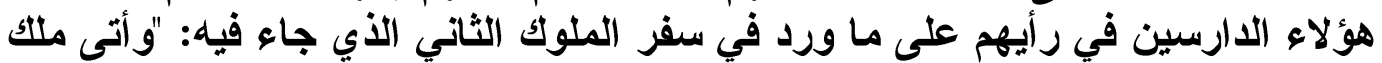

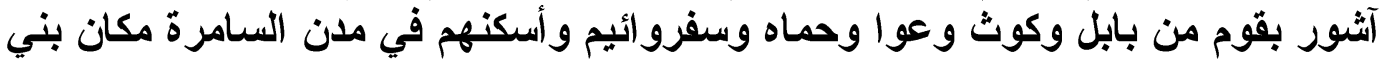

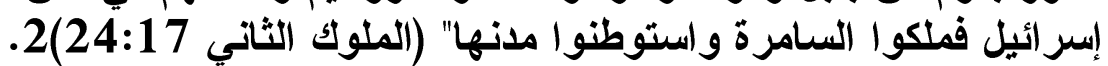

كما يرى البعض من أصحاب هذا الر أي، أن السامرة يحاولون الاتتساب الحى اليهود

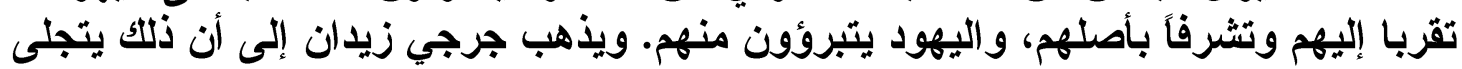




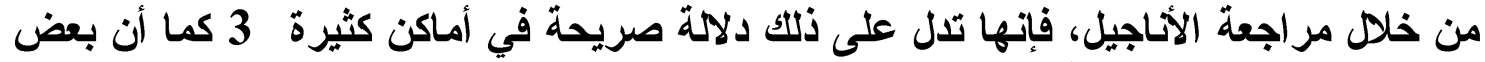

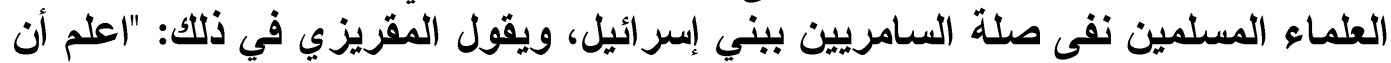

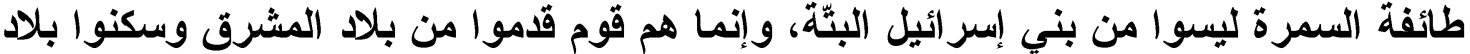

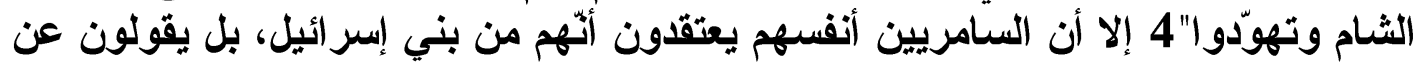

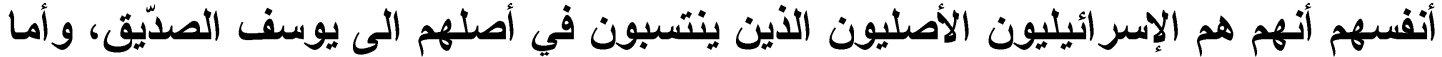

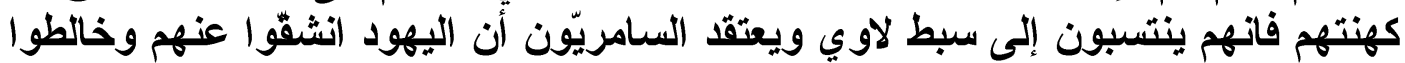

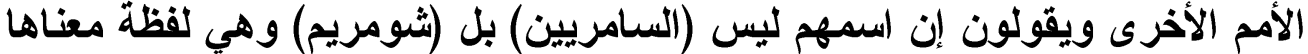

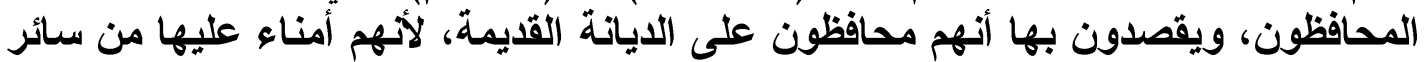

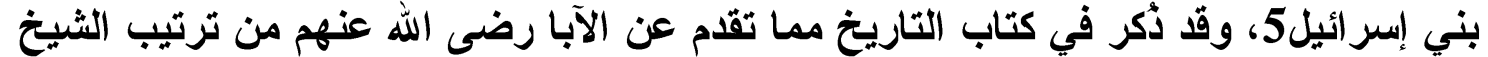

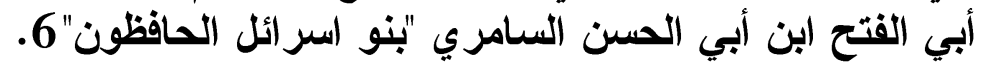

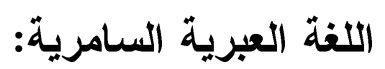

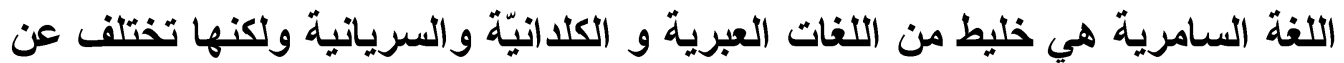

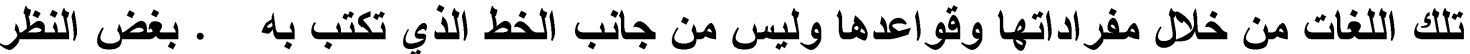

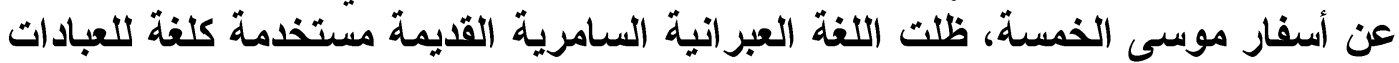

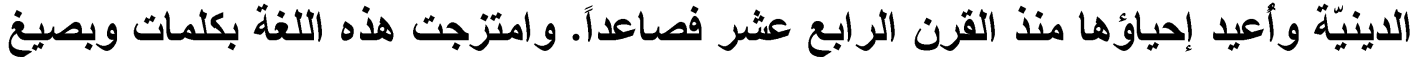

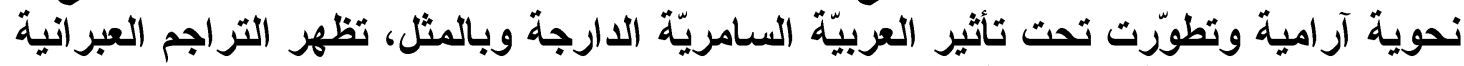

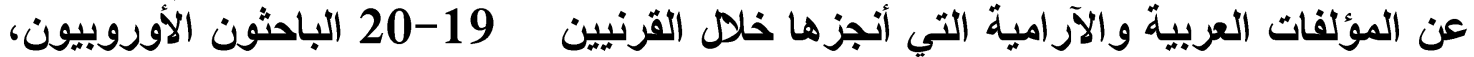

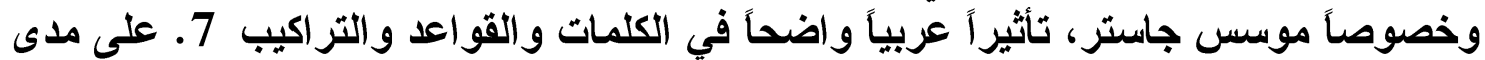

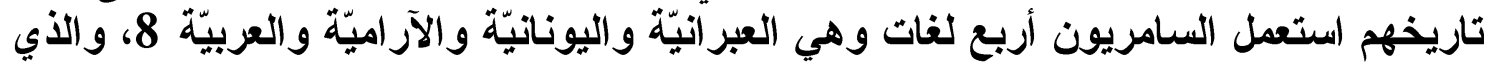
يهميّا في بحثنا هذا هو اللغة العبريّة السنامريّة.

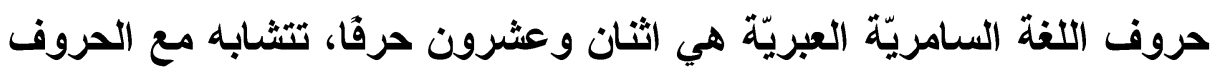

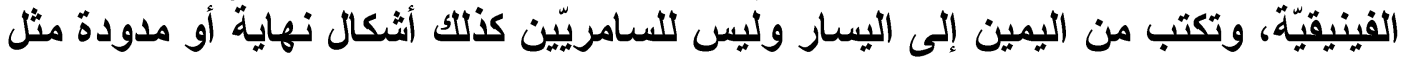

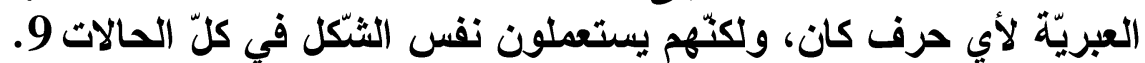

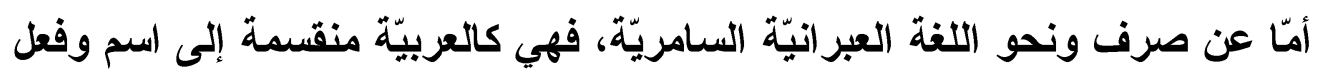

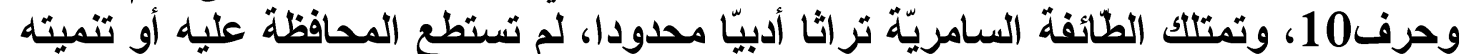

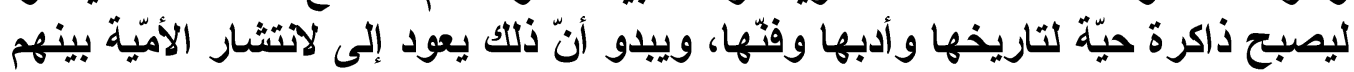

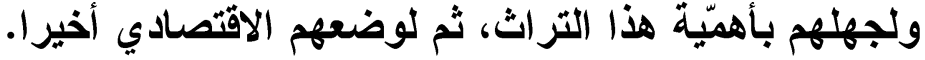

تحتفظ الطائفة الستّامريّة بثلاثة وستيّن مرجعا، وهذا بحسب الدّر اسلة التّاريخيّة في

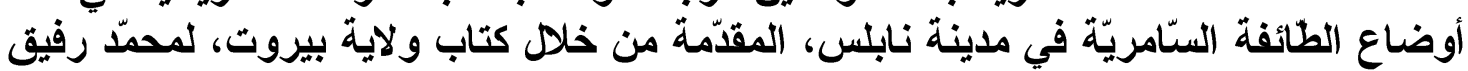

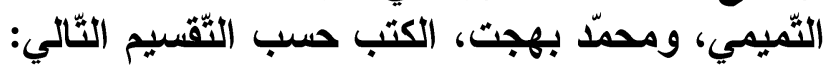

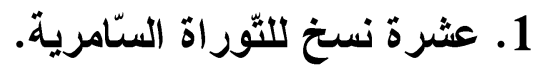

2. اثنان وعشرون تتناول العقائد الاينيّة والأدعية. 
3. تسعة وعشرون تثناول اللفةة والأدب الستّامري.

4. و اثنان مختصنّان بالتاريخ11

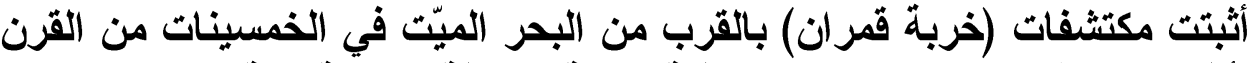

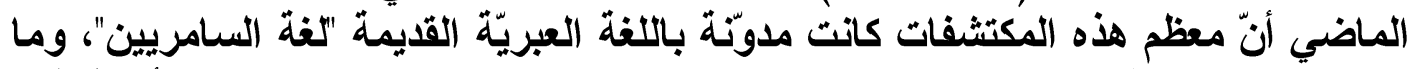

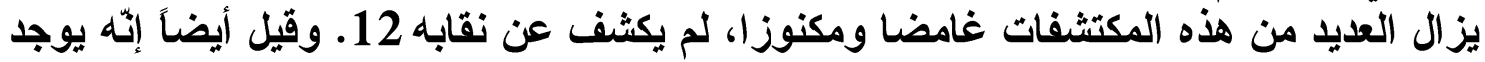

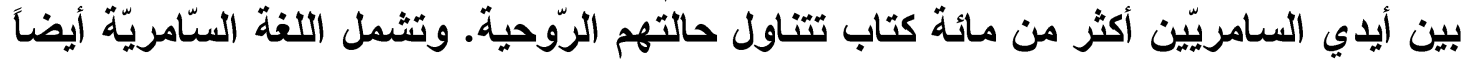

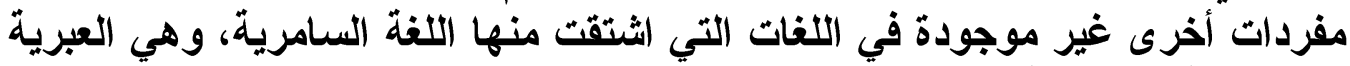

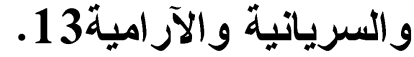

يقول الكاهن عاطف ناجي السيّامري: إنّ السامريين لم يعترفوا باللغة العبريّة الجديدة

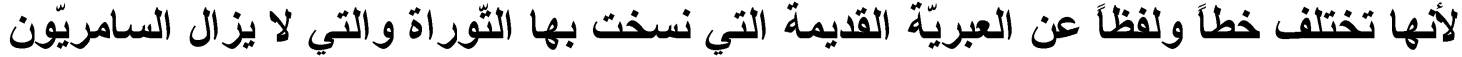

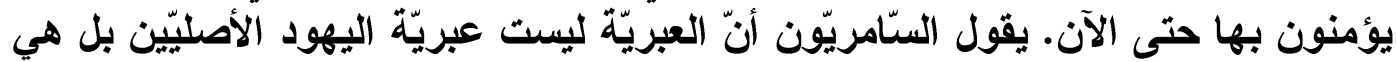

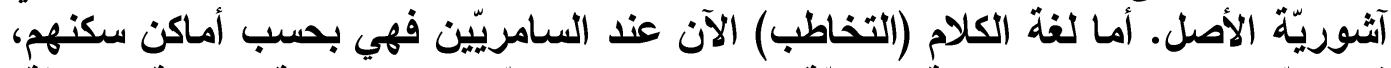

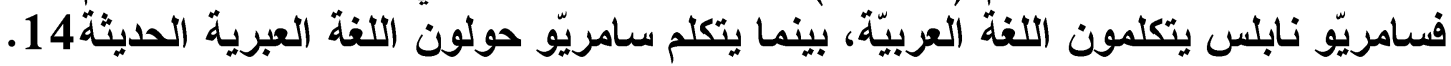

\section{نحو اللغة العبريّة السامريّة:}

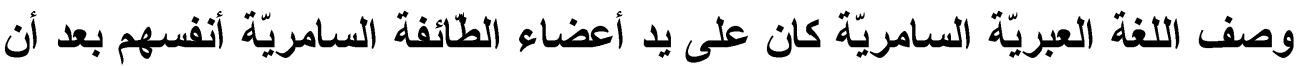

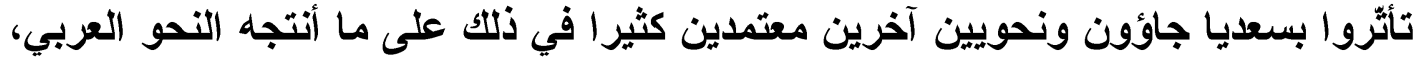

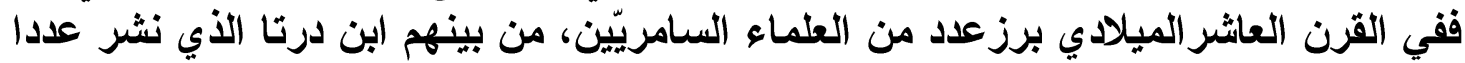

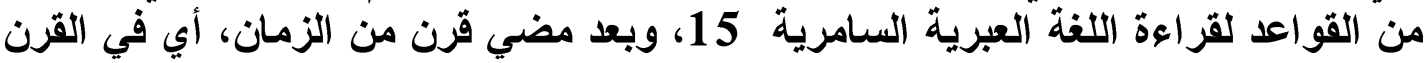

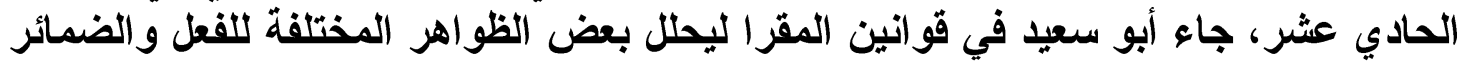

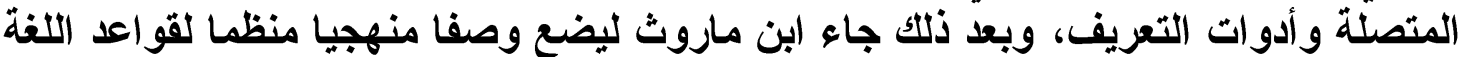

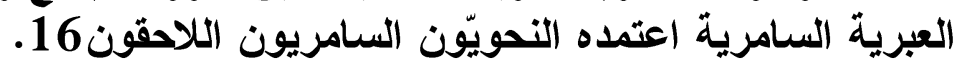

في كتاب التوطيه لا نجد ذكر ا لنحويّين سامريّين سابقين أو أي عمل سابق يتعلق بنحو

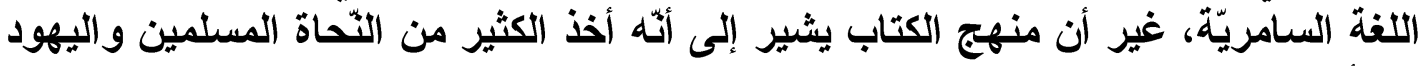

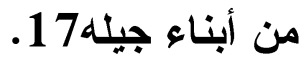

يُعتبر ابن ماروث أولّ من وضع وصفا دقيقا ومنهجيّا للغة العبريّة السامريّة فهو رائد

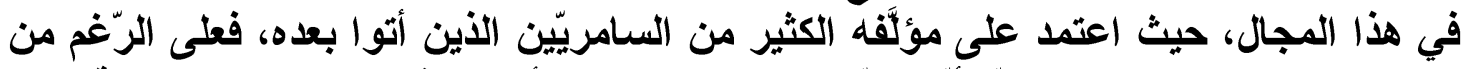

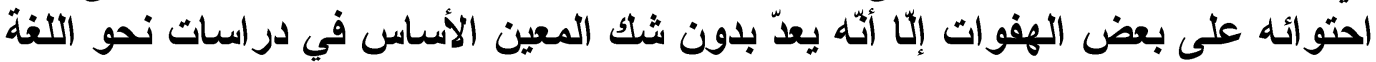

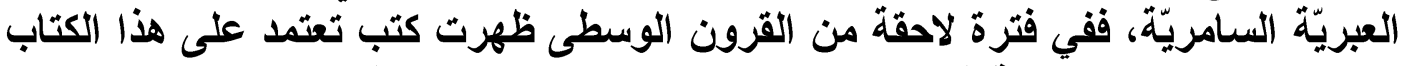

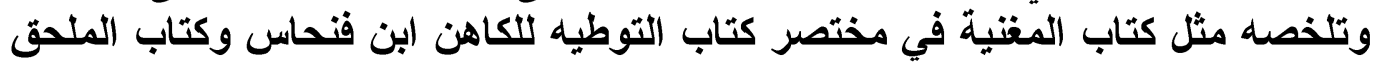
بمختصر التوطيه للثيخ ابن مرجان الانفي 18. وقد عرضي كتئ زئيفي بن حييم قائمة بالنحويّين 


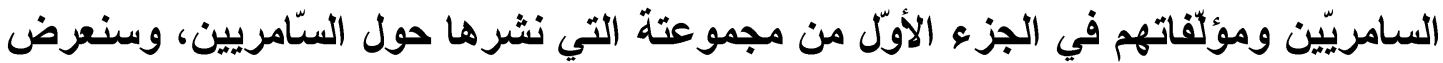

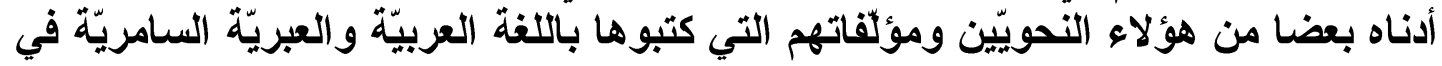
القرون الوسطى:

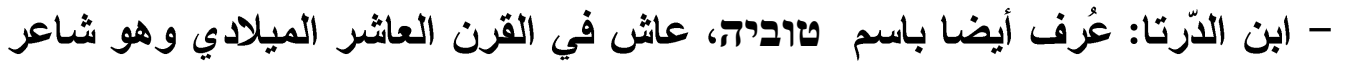

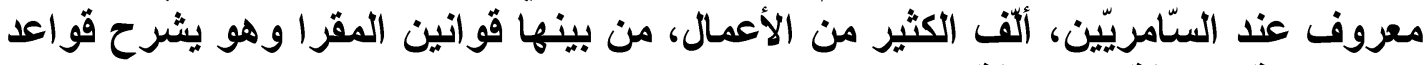
قر اعة اللغة العبريّة السامريّة 19.

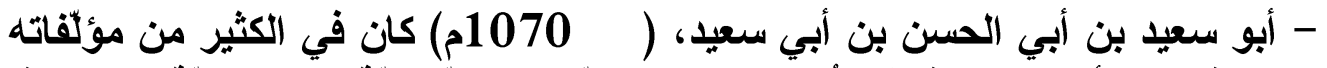

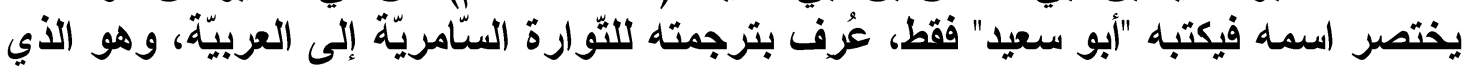
ألفتّ كتاب

خصائص من اللغة العبريّة السامريّة: تم تقسيم تلك الخصائص على أسساس أقسام الكلم الثلاثة الاسم والفعل والحرف أ. الجزء الأول من الكلم هو الاسم: في رسالة تتعلق في القواعد البسيطة كما في

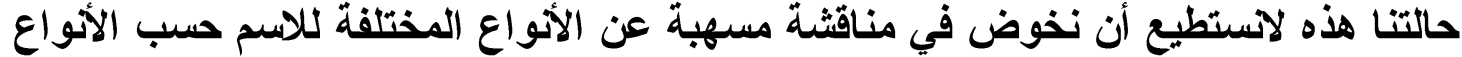

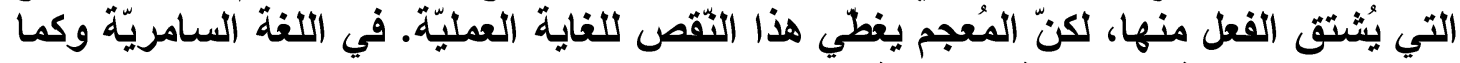

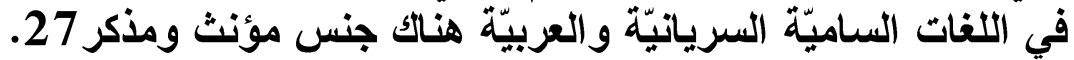

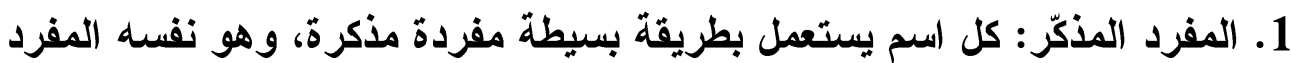

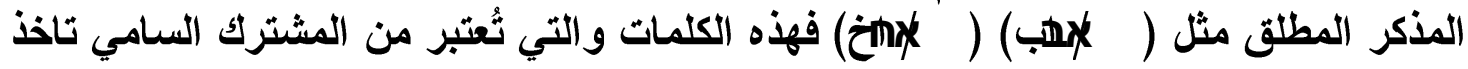

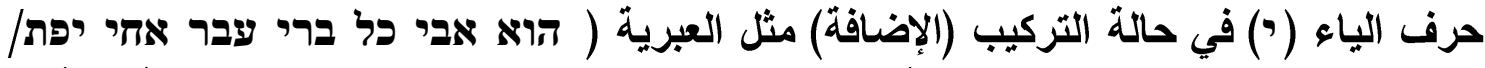

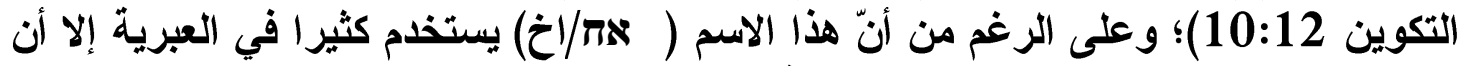

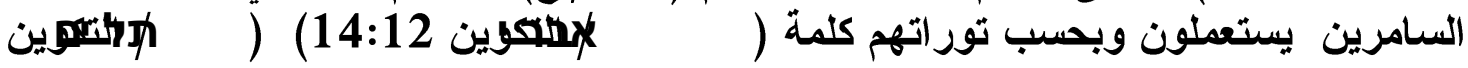

2. المفرد المؤنث: يُشَّل بإضافة حرف ( الها الهاء) إلى نهايته في حالة الإضافة

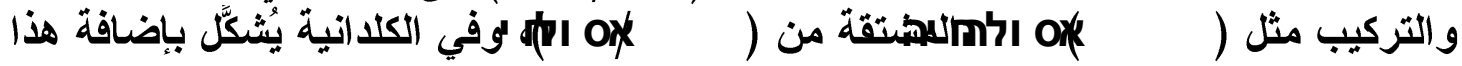

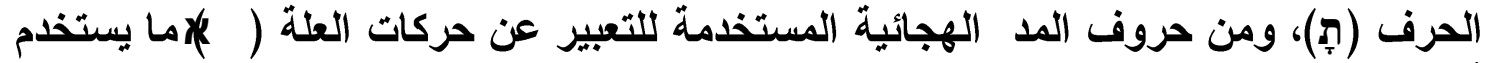

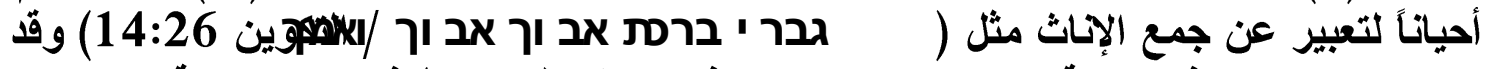

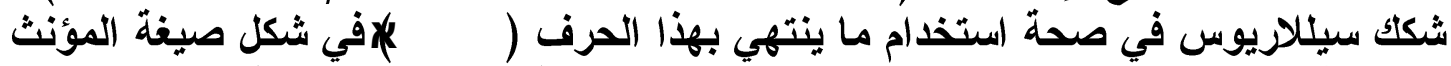

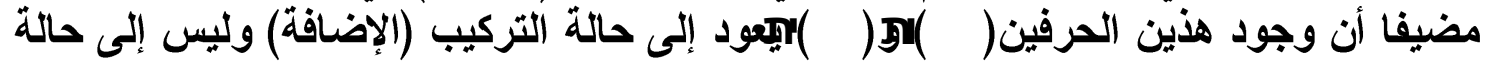


3. الحالة المطلقة، حالة التركيب وحالة الإثبات: فبينما يحافظ الأسم على شكله في

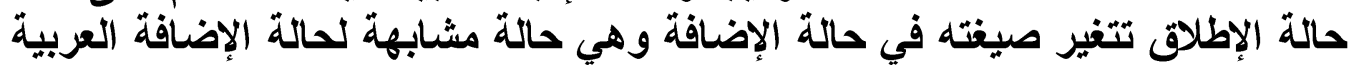

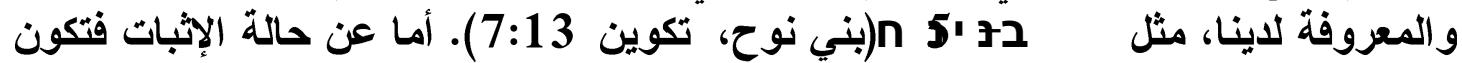

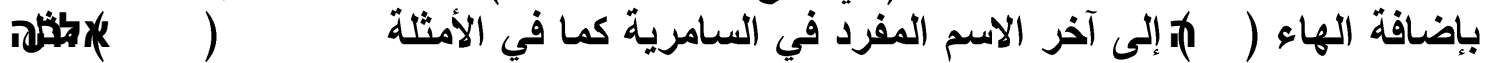

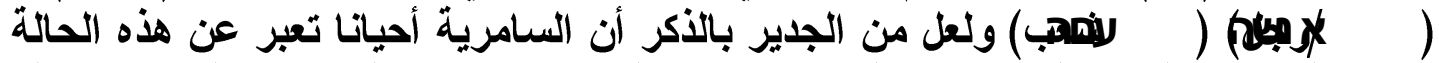

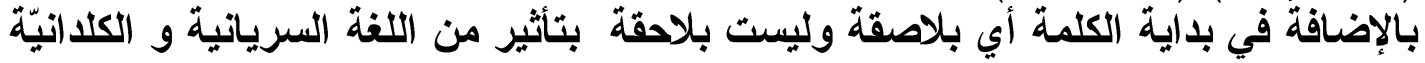

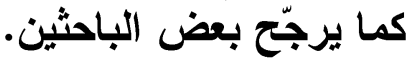

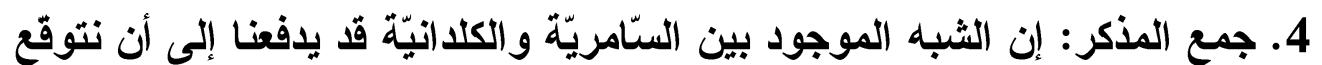

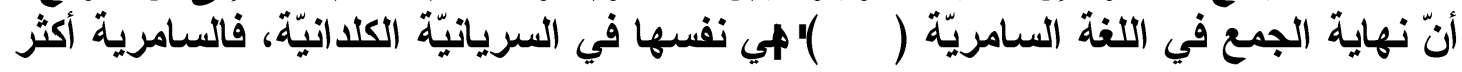

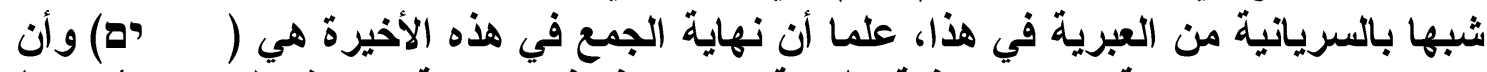

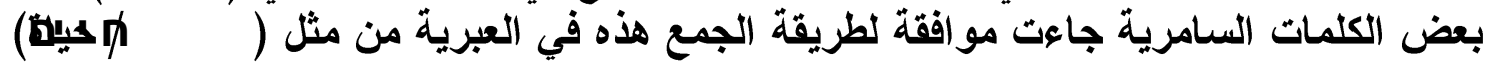

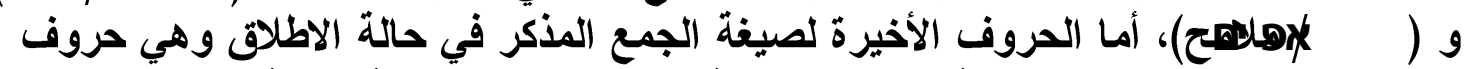

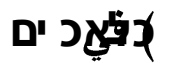

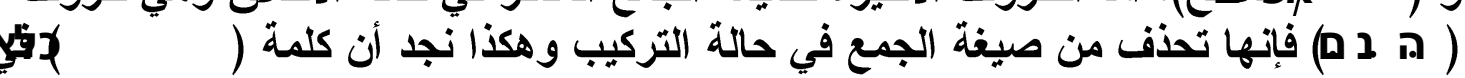

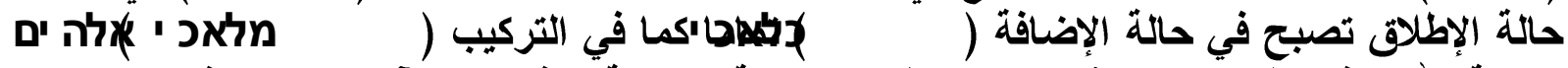

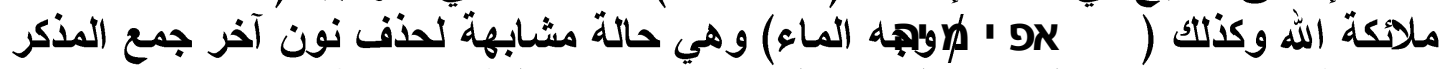

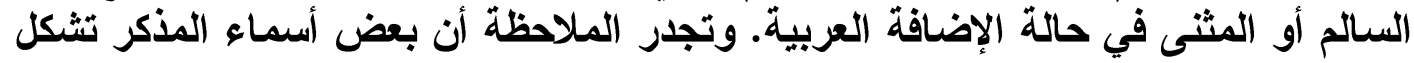

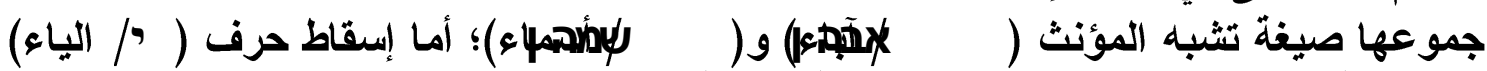

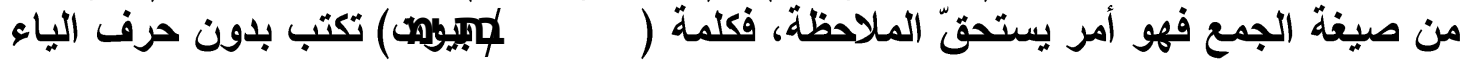

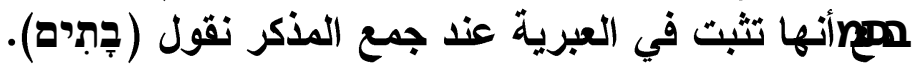

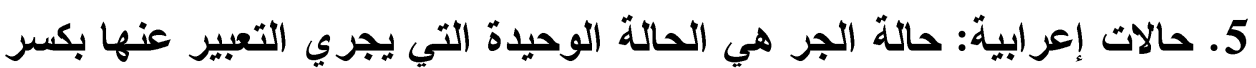

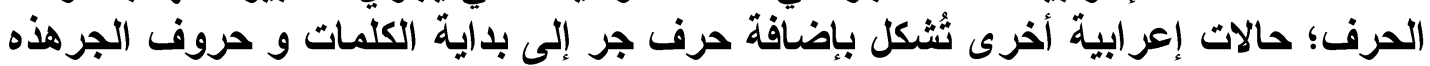

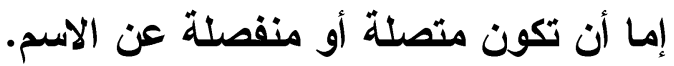

6. درجات المقارنة: هناك ثلاثة درجات للمقارنة في اللغة السامرية العبرية التشابه

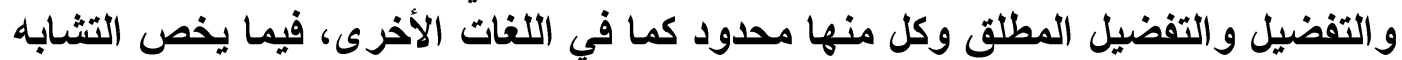

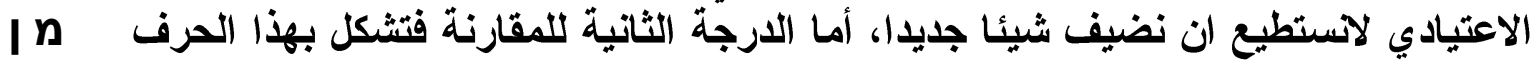

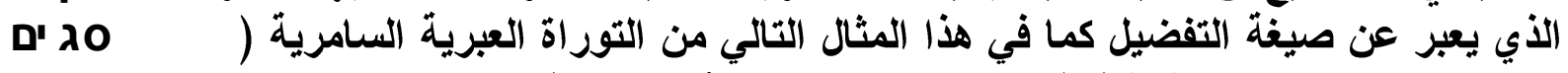

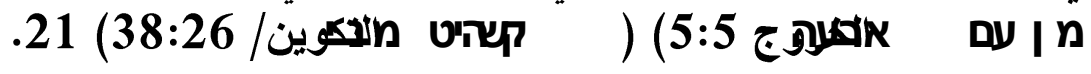

7 7. الضمائر: يمكن تقسيم الضمائر السامرية الى قسمين كما في جميع اللغات الساميّة إلى متصلة ومنفصلة.

أ- الضمائر المتصلة: وتكون لواحق في آخر الكلمات تختلف باختلاف العائد وهو

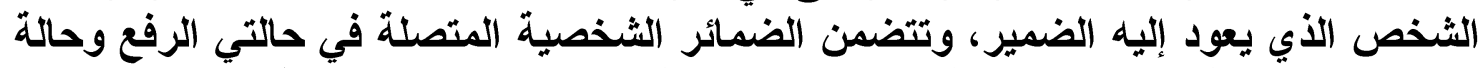

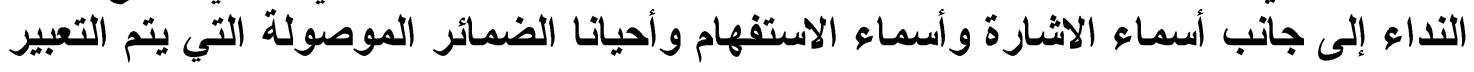




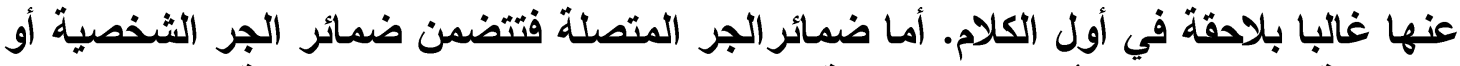

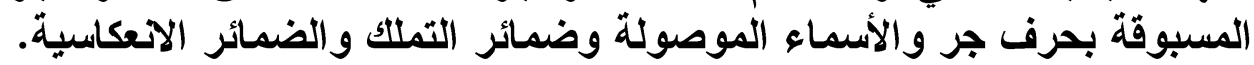

ب- الضمائر المنفصلة: فهي الضمائر الشخصية المعروفة في اللغات الأخرى والتي والثي تعود إلى الثخص الأول والثاني والثالث (المتكلم المخاطب والغائب) للمفرد والجمع.

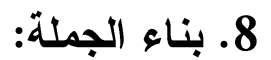

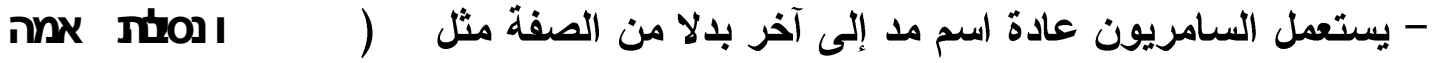

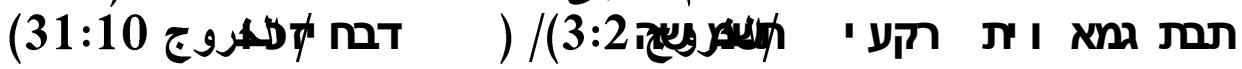

- يُستعمل الاسم أحيانا بلالا من الصفة للتعبير عن المضمون المراد الإخبار عنه المانه

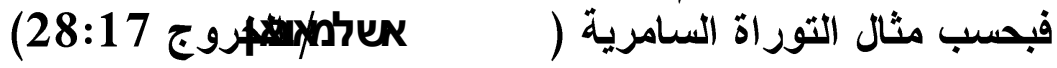

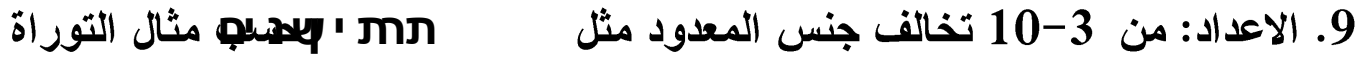

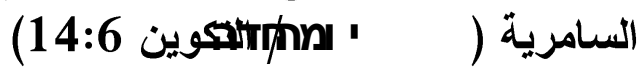

ب. الجزء الثاني من الكلم هو الفعل:

أنواع الفعل، أثنكاله المختلفة، وتصريفاته: وتكون طريقة تغيير بنيان كل نوع أوصيغه من خلا الحالات الإعر ابية المختلفة والأزمنة. 1. النوع المجرد يتكون من الأحرف الأصلية فقط وتنوعاتها وتكون عادة ثلاثة حروف

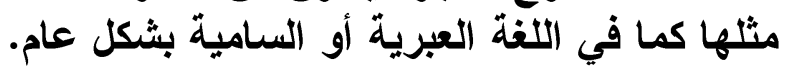

2. الفعل المزيد يتكون من الفعل المجرد بالإضافة إلى الحروف الخوادم التي تثير إلى صيغة استثنائية عن غير الفزئ

4. الباحث ادموند كاستيل في معجمه عن الترجمة السبعينية للكتاب المقدس "اللغة

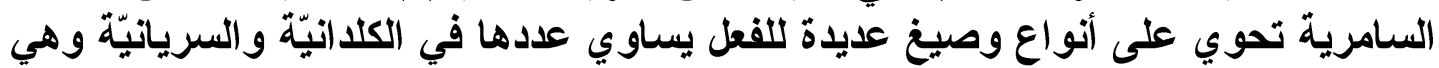

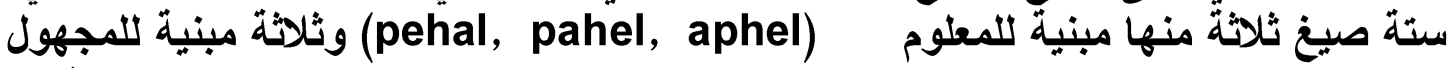

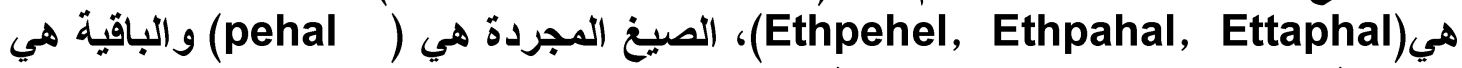
اشثتقاقيّة" . يعتقد مورينوس بوجود ثلاثة تصاريف فقط متميزة استنادا لغياب الحركات

التثقيطية في اللغة السامرية مورينة 22.

5. انتهاء الفعل الماضي الأي يعود الي المخاطب المؤنث بتاء وياء موجود في بعض الاحيان في النص الماسوري. 
كـا 2013

ج. الجزء الثالث من أقسام الكلام هو الحرف : وهنا لابد من الإثارة إلى الحروف السامريّة ومايقابلها من الحروف العربيّة مع لفظها بالسامرية العبرية الابد من الإندار

$$
\text { أ = }
$$$$
\text { ب }
$$

ج

د

ه

$ب+\mathbf{l}=$

j

ي

ط

ي = بُّوت

ك

J

م

ن

س = مك سينئ كات/ سينئ غات

$$
\begin{aligned}
& \text { ع } \\
& \text { ف = فب فِي } \\
& \text { ص = צ صآدِي } \\
& \text { ق = قُوف } \\
& \text { ر }
\end{aligned}
$$




$$
\begin{aligned}
& \text { ش = שـ شان } \\
& \text { ت = }
\end{aligned}
$$

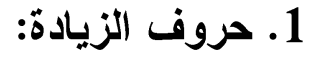

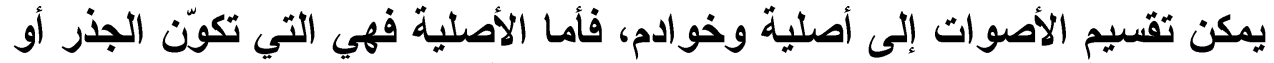

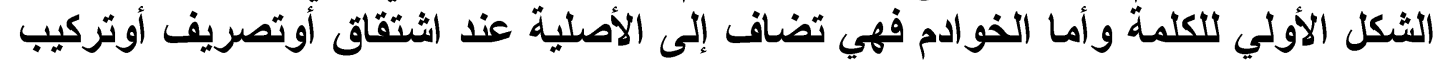

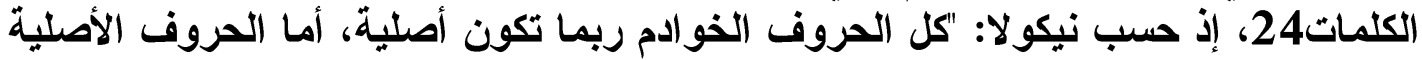

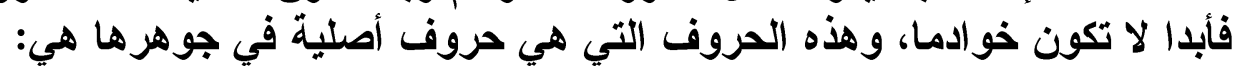

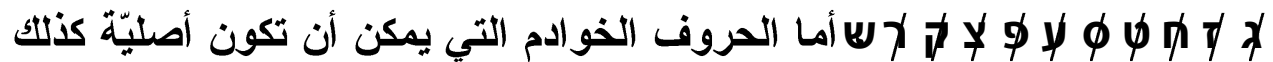
فهي:

$$
\text { 2. أحرف العلة ولفظها: }
$$

ويشير بعض الباحثين إلى أنّ التّوارة السامريّة فيها حروف علّة أكثر مما في العبرانيّة

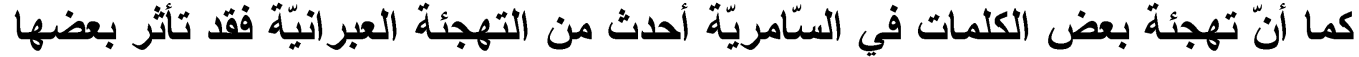

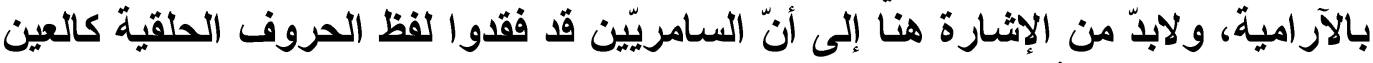

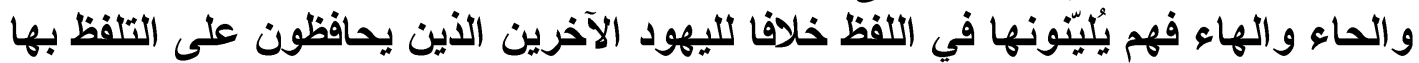
كذبك.

فالسامريّون ليس لايهم نقاط فوق الحروف تثير الحى أحرف العلة بخلاف العبريّة

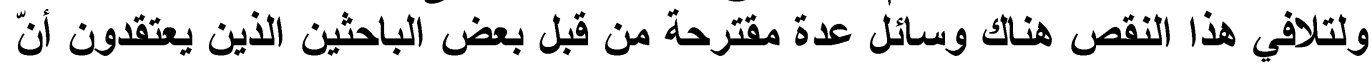

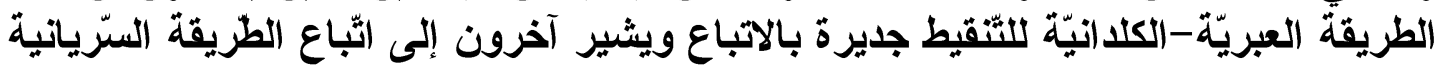

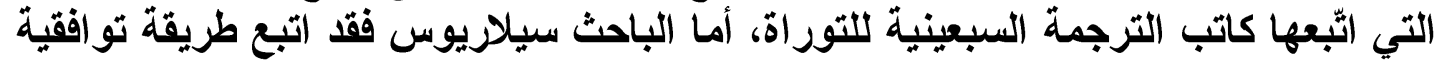

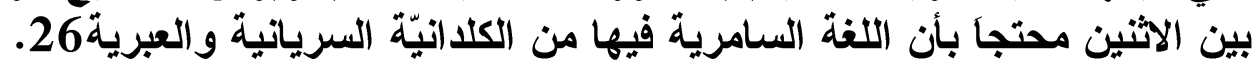

غير أنّه صار من المرجّح القول بأنّ السيّامريّين لم يعرفوا ماعرفه اليهود الآخرين من فئن

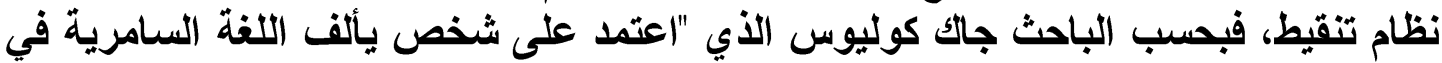

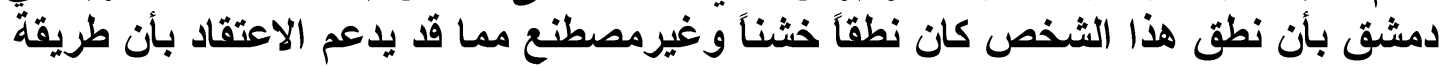

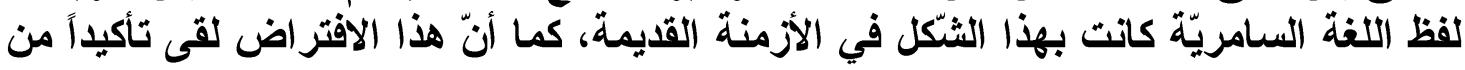

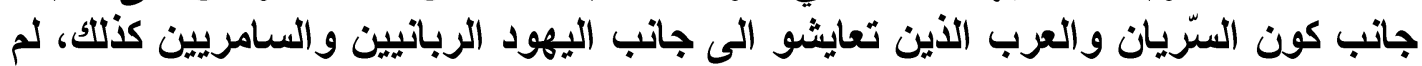

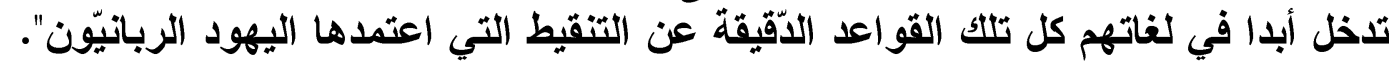
3. 


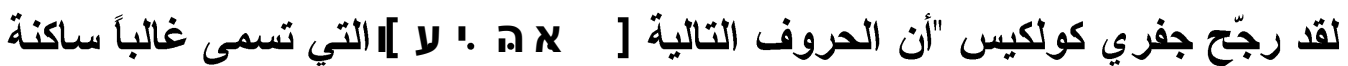

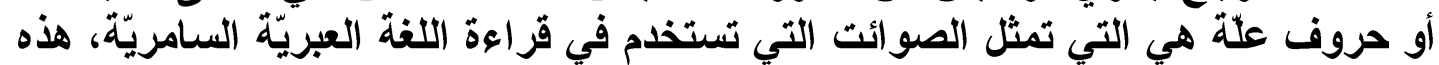

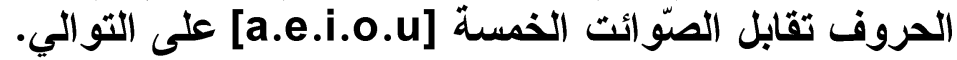

$$
\text { - الصوائت القصيرة }
$$

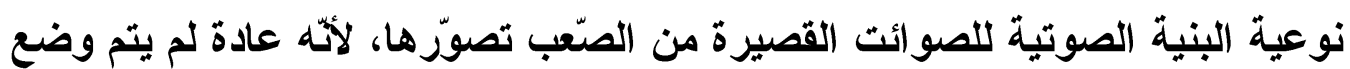

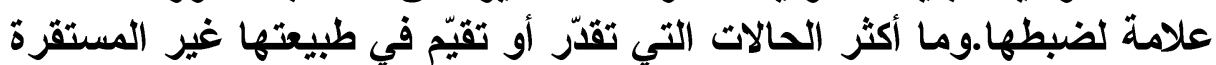

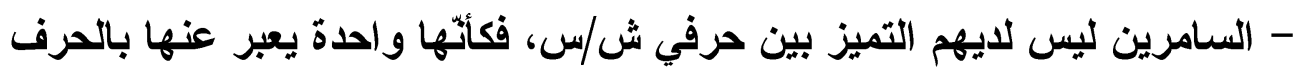

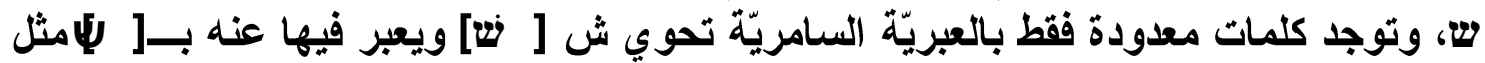

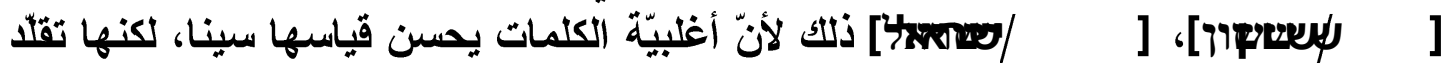

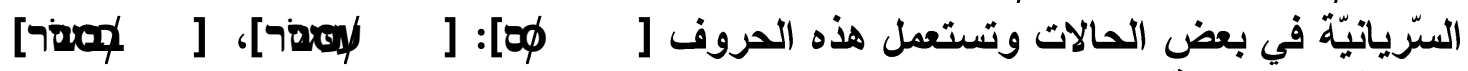

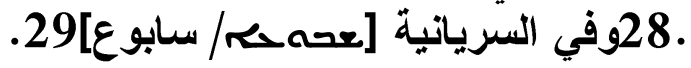

\section{مقارنة بين السامرية و العبرية الطبرية:}

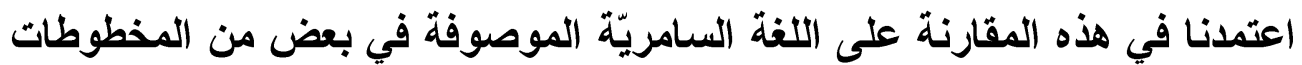

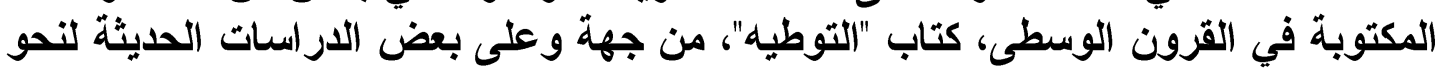

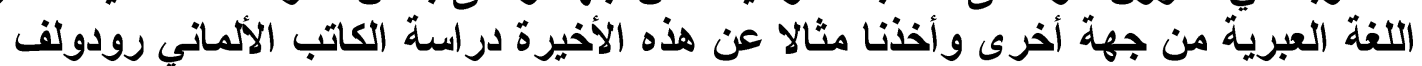

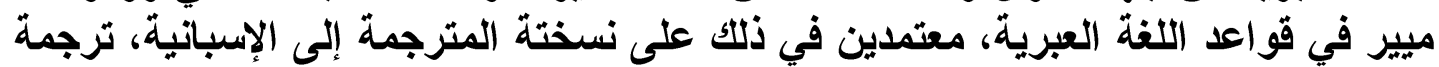

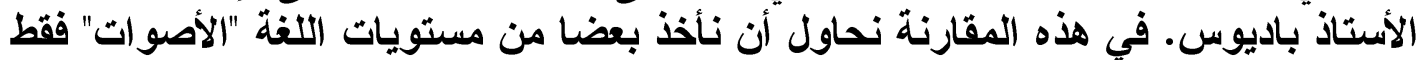
وذللك بقدر ما تتيح لنا مصادرنا من الاطلاع.

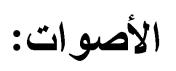

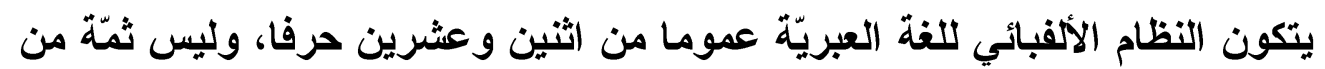

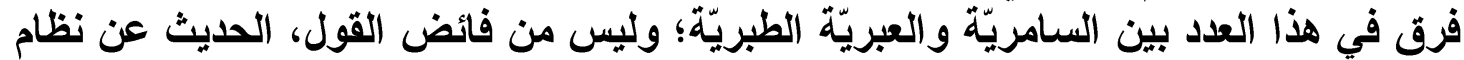
ألفبائي في السامريّة مختلف في رموزه عن والنيّة النظام العبريّة المألوف و المعروف. 
وفقا لمايير، الخط السامريّ، كما نفضل تسميته، ما هو إلا خط عبري كنعاني قايم إنمان

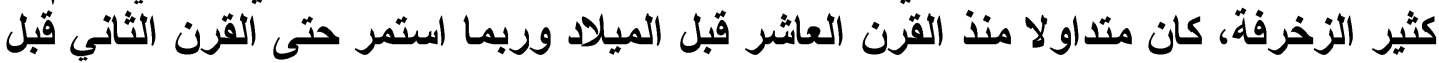

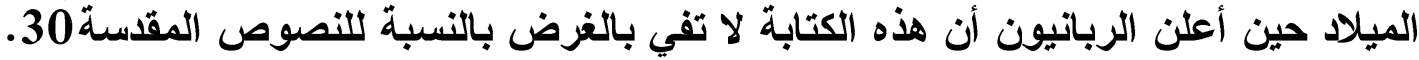

أما عن الخط العبريّ المربّع فهو تاريخيّا يعود إلى نهاية القرن الأوّل الميلاديّ، حين

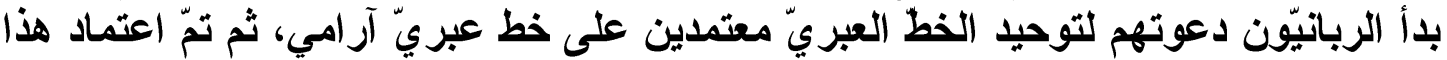

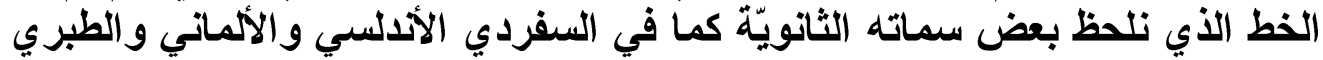

القلسطيني.

الصوامت: في باب الحرف ذكر مؤلف كتاب التوطيه أن حروف ألف باء هي من أن أن فيز

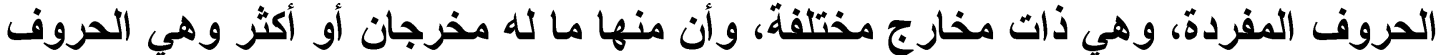

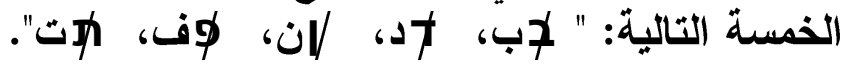

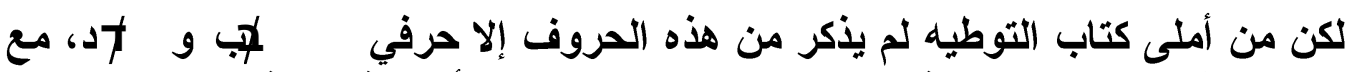

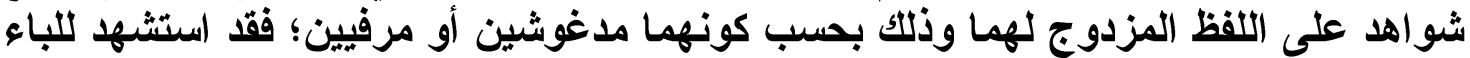

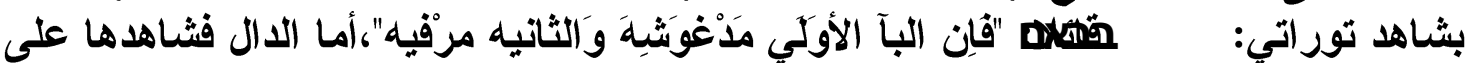

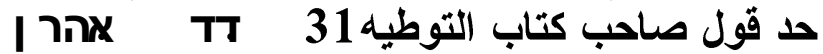

الحالة التي أثار إليها كاتب التوطيه، يمكن ملاحظتها في الطبرية مع اختلاف كمي

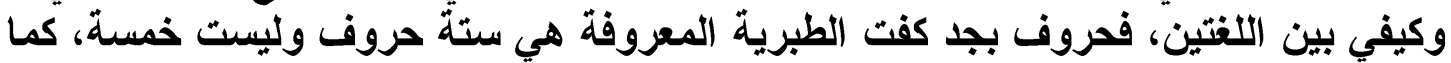

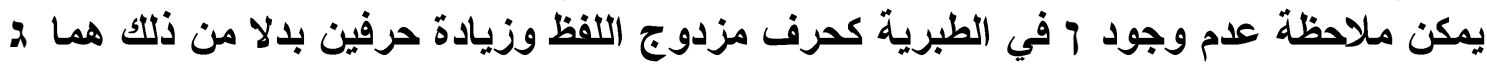
و د في الطبرية.

ومن الجدير بالأكر هنا أن الحروف المذكورة هي عبارة عن تمثيل لأصوات ثنائية

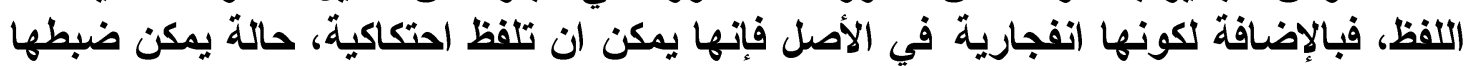

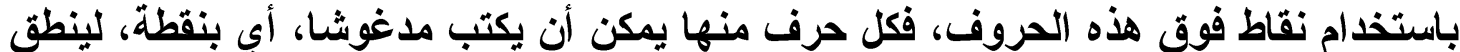

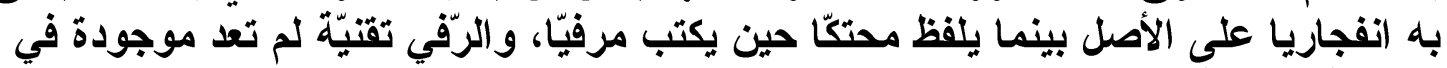
الطباعة الحديثة الطية

لاش: يعبر عن صوتين متمايزين بحسب موقع النقطة فوق الحرف إلى الثمال أم

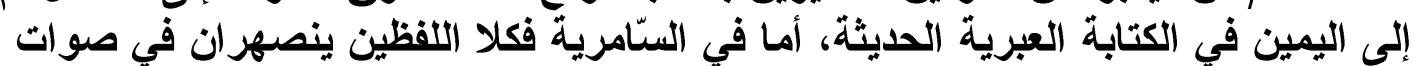

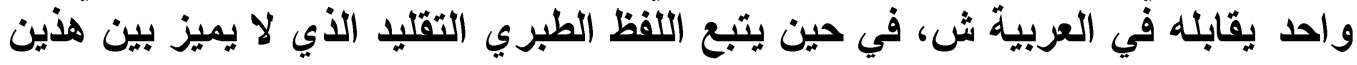
الصوتين.

ومن الجدير بالذكر أن صوث ( جأح) في العصور الوسطى كانت تلفظ بصورتين أيضا،

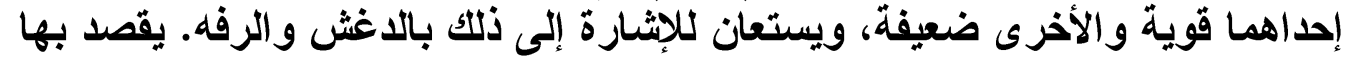
"المنقوطة وغير المنقوطة ولة الاخري". 
الحركات في العبريّة القلسطينية القديمة، ومن بينها السامرية، هي حركات فوق

خطية، بينما تكون ألحركات في الطبرية تحت خطية 33.

|للافظ:

تلعب المنطقة الجغز افية للغة وكذلك التاريخ دورا كبيرا في اختلاف اللفظ بين لغة

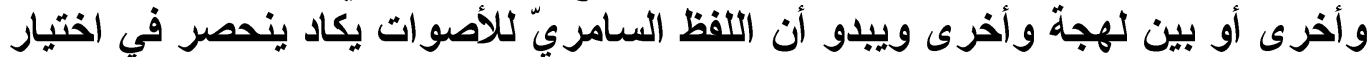

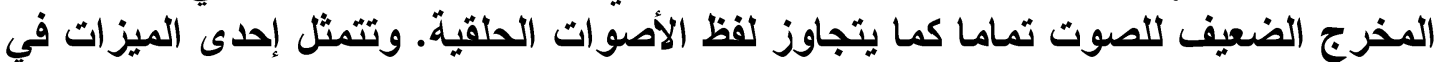

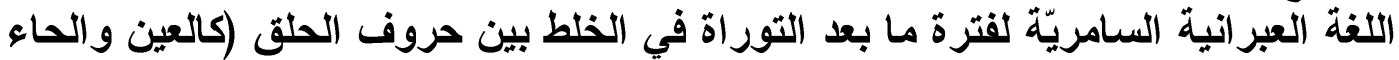

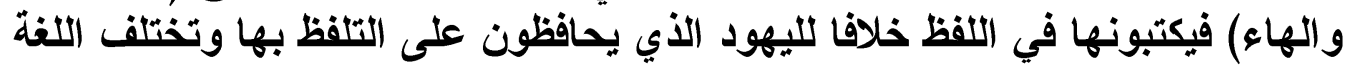
السامرية عن اللغة العبرية، حيث تلفظ الكثمات في الأولى مفتوحة وتنطق إلى فوق، ولثي وتلفظ في العبرية مكسورة وتنطق إلى تحت 34.

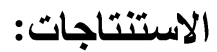

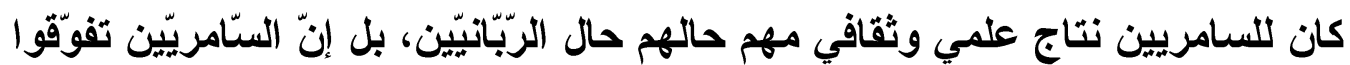

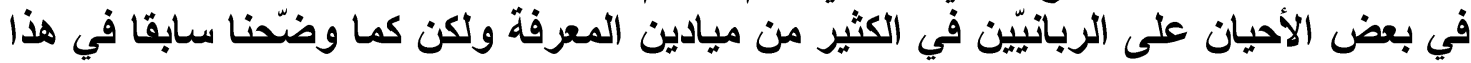

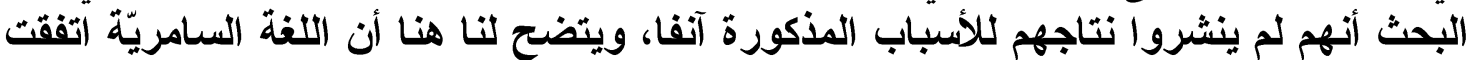

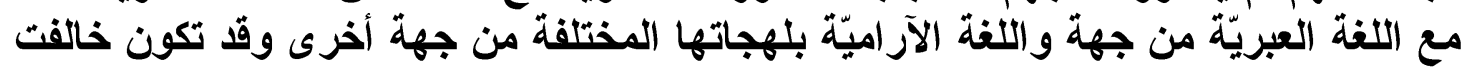

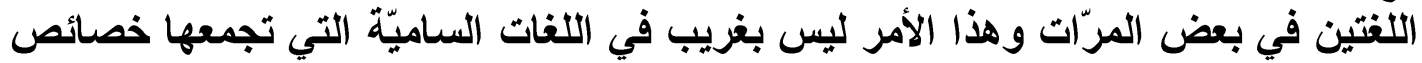

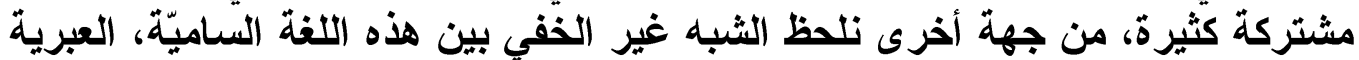

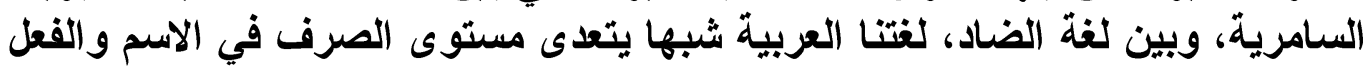

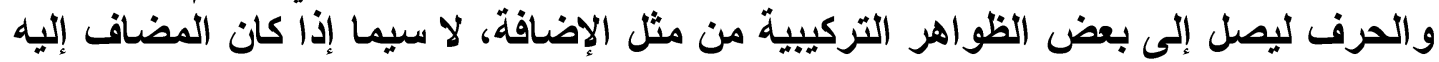

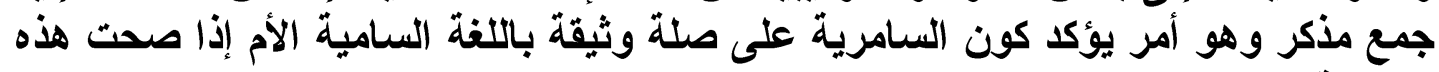

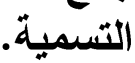

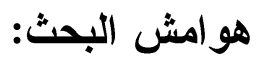

1 الاباغ، مصطفى مر اد: بلادنا فلسطين. الطبعة- الرابعة دار الطليعة بيروت 1988.

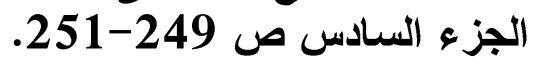

2. The New Encyclopedia Britannica, V.10: pp 373-374. 
3. زيدان، جرجي: (مؤلفات جرجي زيدان الكاملة). دار الجليل بيروت 1982. الجزء

التاسع عشر ص

4. المقريزي، أبو العباس، (

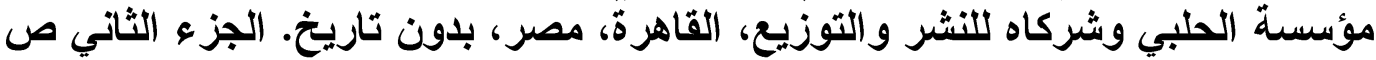

5. مرمورة، إلياس: السامريون. دار الأيتام السورية القد 1934. ص .2

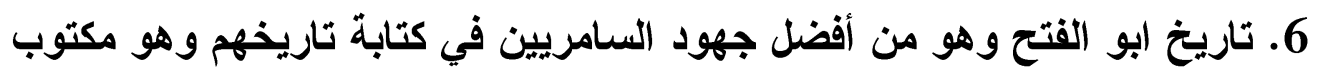

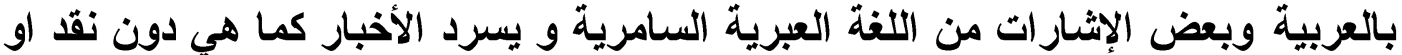

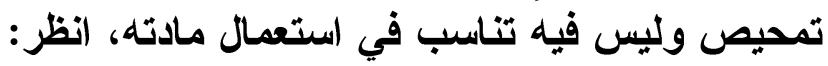

Vilmar, E: Abū al-Fatḥ ibn Abī al-ł̣san, al-Sāmirī , Abulfathi Annales Samaritani, Gothae. 1865. p 52.

7. Encyclopedia Judaica: 17:p 735.

8. Macuch, R: «Samaritan languages: Samaritan Hebrew, Samaritan Aramaic», (ed.), by Grown, Alan D, et al. Mohr Tübingen, 1989. pp. 531-584.

9. ملحم، عدنان: اوضاع الطائفة السامرية في مدينة نابلس من خلال كتاب ولاية بيروت لمحمد رفيق التميمي ومحمد بهجت دراسة تاريخية منهجية. نابلس فلسطين. 12001 الجزء الأول ص 158 159 159.

10. (بن ماروث : كتاب التوطيه، المخطوطاث السامرية- العربية، مكتبة جامعة ليدن، هولندا.القرن الثاني عشر الميلادي. صاب : صابت .40 11 ـ ملحم، عدنان: مرجع سابق الجزء الأول ص 160- 165.

12. Nicholl, George: A grammar of the Samaritan language, with extracts and vocabulary, London: Cambridge 1853. pp 1-2.

13. Nicholl, George: Op. Cit, pp 10-13.

14. الشريدة، محمد حافظ: الطائفة السّامرية تاريخها-عقيدتها- شريعتها-عادتها-

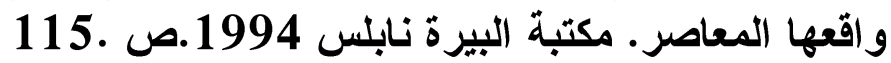

15. Sáenz Badillos, Á A History of the Hebrew Language, New York: Cambridge University Press 1994. pp 149-150. 
16. Sáenz Badillos, Á. Op.cit, pp 151-152.

17. בן חיים، זאב: עברית וארמית נוסח שומרון. כרך ראשון: מבוא، כתבי

הזקדוק. ירושלים תשי"ז 1957 עמי לאי ואר ואית.

$$
\text { 18. בן חיים، זאב: نفس المصدر מו-פז. }
$$

19. حول الموضوع انظر: בן חיים، זאב: مرجع سابق.

20. Nicholl, George: Op.cit, pp 19-24.

21. Nicholl, George: Op.cit, pp23-24.

22. Nicholl, George: Op.cit, pp 27-85.

23. Pummer, R: The Samaritans, Leiden: (Lconography of Religions XXIII,5). 1987. P plate I.

24. Nicholl, George: Op.cit, p 11.

25. Sáenz Badillos, Á. Op.cit, pp 151-156.

26. Nicholl, George: Op.cit, p12.

27. Nicholl, George: Op.cit, pp 30-32.

28. Sáenz Badillos, Á. Op.cit, pp 51-54.

29. Blau, J: A grammar of Christian Arabic based mainly on South-Palestinian texts from the first millennium, 3 vols. Louvain:

Secrétariat Dumbarton Corpus. 1966. P110.

30. Meyer, R: Gramática de la Lengua Hebrea, Tr, de Angel

Sáenz-Badillos. 1989. pp 53 - 54.

$$
\begin{aligned}
& \text { 31. (بن ماروث: مرجع سابق ص 195 - 196 } 196 . \\
& \text { 32. الرفة عبارة عن خط أفقي يكتب فوق الحرف، انظر: } \\
& \text { Meyer, R: Op.cit, p } 59 . \\
& \text { 33. Meyer, R: Op.cit, p } 60 .
\end{aligned}
$$


34. Macuch, R: Op.cit, pp 531-584.

\author{
المصادر

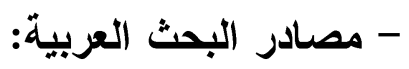

1) (بن ماروث : كتاب التوطيه، المخطوطات السامرية- العربية، مكتبة جامعة ليدن، هولندا.القرن الثاني عشر الميلادي.

2) الدباغ، مصطفى مر اد: بلادنا فلسطين. الطبعة- الرابعة دار الطليعة بيروت

3) الثريدة، محمد حافظ: الطائفة الستّمرية تاريخها-عقيدتها- شريعتها-عادتها-

و اقعها المعاصر . مكتبة البيرة نابلس . 1994

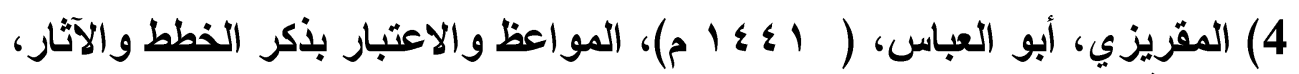

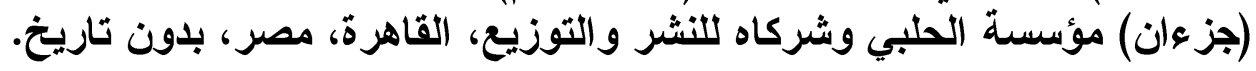

5) زيدان، جرجي: مؤلفات جرجي زيدان الكاملة. دار الجليل بيروت 1982.

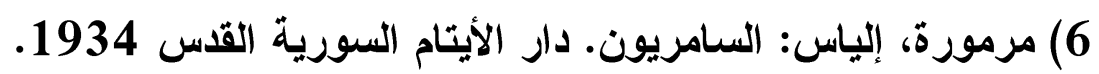

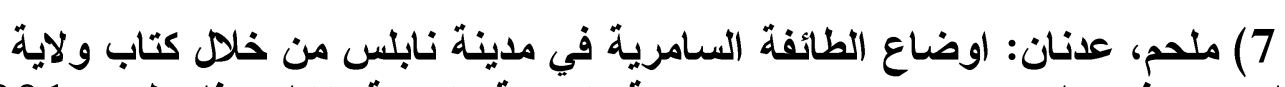
بيروت لمحمد رفيق التميمي ومحمد بهجت دراسة تاريخية منهجية. نابلس فلس فلسطين. 2001.

- مصادر البحث العبرية: - n

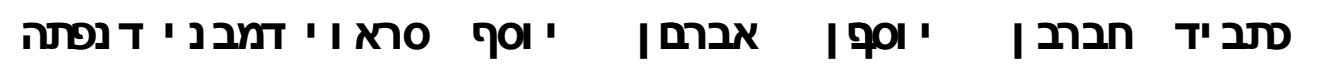

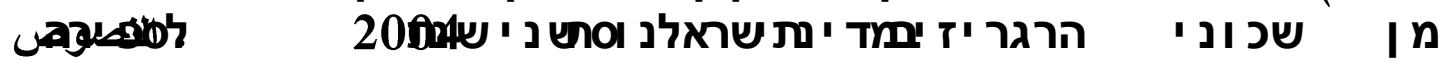
التوراتية المستخدمة في هذا البحث هي من التوراة السامرية العبرية حيث استطعت العيث العصول

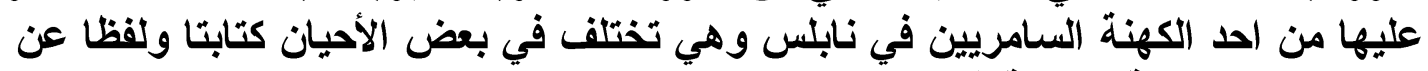

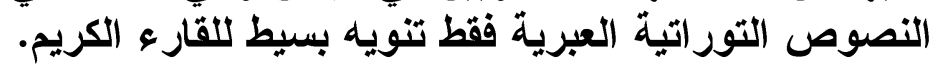

בן חיים، זאב: עברית וארמית נוסח שומרון. כרך ראשון: מבואי כתבי

הזקדוק. ירושלים תשי"ז 1957. 


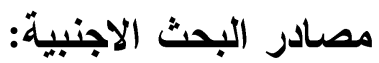

10_Blau, J, A grammar of Christian Arabic, based mainly on South-Palestinian texts from the first millennium, 3 vols. Louvain: Secrétariat Dumbarton Corpus. 1966.

11_ Encyclopaedia Judaica v. 17.

12_Encyclopedia Britannica, v. 10.

13_ Macuch, R., «Samaritan languages: Samaritan Hebrew, Samaritan Aramaic», (ed.), by Grown, Alan D, et al. Mohr Tübingen.

14_ Meyer, R, Gramática de la Lengua Hebrea, Tr, de Angel Sáenz-Badillos. 1989.

15_ Nicholl, George F., A grammar of the Samaritan language, with extracts and vocabulary, London: Cambridge 1853 .

17_ Pummer, R., The Samaritans, Leiden: (Lconography of Religions XXIII,5). 1987.

18_ Sáenz Badillos, Á A History of the Hebrew Language, New York: Cambridge University Press 1994.

19_ VILMAR, E., Abū al-Fatḥ ibn Abī al-ł̣san, al-Sāmirī, Abulfathi Annales Samaritani,Gothae. 1865. 1865. 